\author{
Steven Cohen \\ William Eimicke \\ Jessica Horan \\ Columbia University
}

\title{
Catastrophe and the Public Service: A Case Study of the Government Response to the Destruction of the World Trade Center
}

\begin{abstract}
The destruction of the World Trade Center on September 11, 2001, resulted in a rapid response by government to evacuate the area and, in subsequent days, to bring the city back to a semblance of normalcy. This article provides a case study of government action in New York City during and after the World Trade Center catastrophe. What is most striking is the skill and intensity of government's response to the emergency and the hard work, dedication, and bravery of New York City's government officials. This article presents government and public service at its finest, under some of the most difficult conditions one can imagine.
\end{abstract}

\section{Learning from the Unthinkable}

This article presents a chronology of events subsequent to the attack on the World Trade Center and analyzes the role of leadership and standard operating procedures in crisis management. It tells the story of the mayor and his team of emergency response advisors and staff. We describe and assess the role of local elected officials in reassuring the city's residents, boosting morale, and preventing disorder after the catastrophe. We also provide profiles of the actions of local public servants.

One purpose of this article is to present a positive story of public service and the centrality and importance of government leadership in emergency response. The role of private citizens, private firms, and volunteers will be discussed. The article also recounts the fiscal impact of the event on New York City's government and the impact of this catastrophe on resource allocation for government emergency response. Finally, we analyze the lessons learned in the response action and conclude with steps to be repeated and avoided in future emergency response actions.

\section{The Catastrophe and the Response Described}

\section{September 11, 2001}

At 8:00 a.m. on September 11, 2001, local New York
City officials knew the importance of the day ahead. It was primary election day, and for many, September 11 had the potential to redefine and transform their political careers. By 9:00 a.m., the election had been overshadowed by the crash of American Airlines Flight 11 into the North Tower of the World Trade Center (Wall Street Journal 2001). Minutes later, a second plane, United Airlines Flight 175, crashed into the South Tower of the World Trade Center. New York City was under attack. In less than one hour, the priorities of government officials in New York and across the nation had shifted dramatically — command centers and triage centers replaced voting booths, while news organizations posted emergency phone numbers rather than voter

Steven Cohen is the director of the executive MPA program and the graduate program in Earth Systems Science, Policy and Management at Columbia University's School of International and Public Affairs. He is the author of The Effective Public Manager (1988), coauthor of Environmental Regulation through Strategic Planning (with Sheldon Kamieniecki, 1991), and coauthor of Total Quality Management in Government (with Ronald Brand, 1993). Email: sc32@columbia.edu.

William Eimicke is the director of the Picker Center for Executive Education at Columbia University's School of International and Public Affairs. Cohen and Eimicke are the coauthors of The New Effective Public Manager (1995), Tools for Innovators: Creative Strategies for Managing Public Sector Organizations (1 998), and the Effective Public Manager (3rdedition, 2002). Email: wbe $1 @$ columbio.edu.

Jessica Horan received her master of public administration in 2002 from Columbia University's School of International and Public Affairs. Email: iph123@columbia.edu. 
turnout rates. Most important, partisan politics were put aside in favor of four mutual goals: safety, communication, funding, and recovery for New York City.

Like many Americans, New York City mayor Rudolph Giuliani's breakfast was interrupted by a telephone call alerting him of a horrible accident at the World Trade Center's North Tower (Seifman 2001). Giuliani quickly finished the meal he was sharing with top aide Denny Young, and the two drove downtown from the 50th Street restaurant toward City Hall. Within minutes, the mayor's phone rang again, this time alerting him of a plane hitting the South Tower of the World Trade Center. Giuliani changed his route and headed directly to the scene.

As Giuliani raced to the World Trade Center from the north, Richard Sheirer, director of New York City's Office of Emergency Management rushed to the World Trade Center from the south. Established in 1996 by Mayor Giuliani in response to the 1993 World Trade Center attack, the office acts as a liaison between all city agencies involved in emergency situations (Sandberg 2001). Prior to September 11, Sheirer's responsibilities included controlling the city's rat population and communicating information to residents about impending snowstorms.

On this day, Sheirer's priority was securing lower Manhattan. To this end, he ordered the police department to close all roads below Canal Street, as well as all tunnels and bridges. He also activated the city's Emergency Operations Center, a $\$ 13$ million, 50,000-square-foot "watch command" located on the 23rd floor of 7 World Trade Center (Bowles 2001). Housing numerous telecommunications and security systems, the Emergency Operations Center was expected to serve as the core logistics center for as many as 68 city agencies immediately following the attacks (ArcNews Online 2002). From here, Sheirer, Mayor Giuliani, and personnel from organizations including the New York Police Department (NYPD) and the Federal Emergency Management Agency could collect and redistribute orders and updates to both law enforcement and residents.

When the second plane hit, debris flew into 7 World Trade Center, forcing Sheirer to evacuate the Emergency Operations Center and set up a command center in the lobby of the North Tower (Campo-Flores 2001). Sheirer then ordered the Coast Guard to seal New York harbor and asked the Pentagon to close the city's airspace (Griscom 2001). Concerned about additional attacks, Sheirer spoke with NYPD brass, which agreed that its helicopter pilots should be prepared to crash their choppers into any other planes attempting to attack the city (CBS News 2002).

Shutting down lower Manhattan facilitated quicker movement of emergency workers and supplies to the "hot zone" (Archibold 2001). Police commissioner Bernard Kerik spearheaded the latter effort. Kerik met Giuliani and several top fire department officials near the base of the
Twin Towers just as the second plane hit at 9:03 a.m. (Marzulli 2001). Unable to contact the Emergency Operations Center, the staff moved to a makeshift command post at 75 Barclay Street to avoid the falling debris. Here. Giuliani, Kerik, and top aides received briefings about the unfolding situation and, from that location, managed initial safety actions and communications. During this time, Giuliani conferred with Sheirer, who directed the closure of all nonemergency activity and entrants below 14 th Street.

Just as Sheirer attempted to communicate with federal officials in the Capitol, Kerik tried to coordinate efforts with NYPD officers throughout the five boroughs. Yet, like most offices located in lower Manhattan, access to telephone, cellular, pager, and email communications was sporadic. Nevertheless, Kerik was able to put the department on "Condition Omega," its highest state of alert (Marzulli 2001). Established in preparation for terrorism threats coinciding with $\mathrm{Y} 2 \mathrm{~K}$, Condition Omega "calls for lightning action minutes after any incident, with thousands of New Yorkers being stopped and questioned and entire sections of the city being closed off" (Marzulli 1999, 6). As Kerik coordinated the overall response of the department, officers from the NYPD, fire department, and Port Authority worked methodically to evacuate approximately 25,000 people from the World Trade Center complex.

Four minutes after the United flight crashed into the World Trade Center, the first NYPD Emergency Service Unit arrived on the scene (McPhee and O'Shaughnessy 2001). Carrying rescue harnesses, hand and hydraulic tools, ropes, and medical supplies, four teams of five to six Emergency Service Unit workers climbed the North Tower stairways, "administering first aid where necessary." When alerted to the South Tower plane crash, two of the Emergency Service Unit teams headed for that building, and more police arrived on the scene to support the effort. Machine guns and extra handguns now supplemented medical and rescue equipment.

Also climbing the stairs to aid rescue efforts were members of the Fire Department of New York (FDNY), who arrived on the scene about the same time as the Emergency Service Unit. They entered the North Tower and immediately began directing people down the stairwells and out of the building via the former floor-to-ceiling glass walls of the mezzanine that had been shot out by a Port Authority officer. By this time, Deputy Fire Chief Peter Hayden commanded evacuation of the entire World Trade Center area. Supporting the 500 firefighters in the Twin Towers were approximately 200 Port Authority police officers (McPhee and O'Shaughnessy 2001), many of whom were already in the building, as the Port Authority had offices within the World Trade Center complex (Schwaneberg 2001).

Supporting the FDNY effort was the department's commissioner, Thomas Von Essen. A firefighter for 26 years 
before becoming commissioner in 1996, Von Essen's presence in the World Trade Center was to "support, help get resources and criticize ... [to] break their chops a little," and to give recommendations for evacuation to Mayor Giuliani" (Mashood et al. 2001, 8). As numerous fire chiefs and tour commanders were also present, Von Essen resisted making operating decisions and instead headed for the Emergency Operations Center at 7 World Trade Center. At that point, the event was "still exciting" for himself and many of the firefighters.

Just minutes after Giuliani and Kerik had settled in to their newest makeshift command post at a nearby firehouse, the South Tower collapsed at 9:59 a.m. and blockaded the group in the building. Von Essen, after finding the Emergency Operations Center evacuated, watched the tower fall while walking toward the mayor's temporary headquarters. "Immediately ... the magnitude of the loss was evident to him without having to hear any numbers" (Mashood et al. 2001, 8). After two more attempts to set up command posts, the mayor, police, Office of Emergency Management director, and newly arrived FDNY commissioner settled in at the library of the police academy. For the next 48 hours, their teams worked feverishly to secure the city and its people from this unpublicized location.

While many public officials and agencies worked together to coordinate evacuation and security efforts, others, by design or by chance, worked alone. This included Transportation Commissioner Iris Weinshall, who was at the Department of Transportation's executive office in lower Manhattan when the first plane hit. Her first action was to determine what to do with all the people in her building. That decision was made for her when the NYPD arrived, requesting they evacuate the space. Officers conveyed additional information about the situation, including details about the evacuation of the Emergency Operations Center at 7 World Trade Center. "[I realized that] the chain of command was completely broken," said Weinshall. "The Office of Emergency Management site was struck, and phone and power lines were down at City Hall. At that moment, I was in charge of my own destiny until I could hook up again with someone at City Hall" (Mashood et al. 2001, 13).

As transportation commissioner, Weinshall's responsibility included oversight of most streets, roads, traffic lights, tunnels, and bridges for New York City (Mashood et al., 2001). The Transportation Department runs the Franchise Bus System, the fourth-largest commuter bus system in the nation, as well as the Staten Island Ferry. On the morning of September 11, Weinshall contemplated how to use these transportation systems to quickly and efficiently get people out of lower Manhattan. Weinshall's efforts were complemented by her staff, most of whom decided to stay in the office to help the evacuation effort, even after the evacuation announcement. By morning's end, Weinshall had moved their base of operations to a small operational facility at 158th Street, where she and her team remained for the next two and a half days.

Even though she was isolated in Washington Heights, Weinshall set up a system of ferries and express and franchise buses to escort people out of Manhattan (Mashood et al. 2001). Here, watercraft corralled from the Transportation Department's purview, party-boat companies, the NYPD harbor unit, and commercial tugboat companies worked together to transport approximately half a million people out of Manhattan by 6:00 p.m. Overseeing evacuation by bus was Transit Police Chief Michael Ansbro, who ordered 50 to 60 buses to transport civilians to Brooklyn, where the buses picked up emergency personnel to bring back into Manhattan.

Though buses and boats were used throughout the day to escort people out of lower Manhattan, PATH trains traveling underneath the World Trade Center evacuated approximately 3,000 people in the first minutes after the attacks (McPhee and O'Shaughnessy 2001). While standing on the concourse of the World Trade Center station, PATH deputy director Victoria Cross Kelly observed several police officers ordering people to leave the area. Though she was unaware of the enormity of the situation, she understood that incoming PATH trains needed to stop letting commuters disembark at the station. Kelly contacted trainmaster Richie Moran, who then directed one incoming train to skip the World Trade Center stop and return to New Jersey. Another train's passengers were unloaded at a stop in New Jersey and then routed to the World Trade Center station to evacuate civilians on site. Kelly and Moran's timely actions assisted in the evacuation of approximately 3,000 civilians.

As Giuliani, Kerik, Weinshall, and many others tackled larger-scale issues facing New York City that morning, a few city officials experienced the day as many New York residents did, immersed in the intimate, individual responses of the evacuation effort. A member of City Council for more than 25 years, Peter Vallone was in the midst of the mayoral primary on September 11. When Vallone learned of the attack, he stopped campaigning, but was unsure of what immediate assistance he, as city council speaker, could provide to affected citizens. So for the remainder of the day, Vallone stood by the 59th Street Bridge and handed out food and water to the thousands of individuals streaming out of Manhattan on foot. For hours, he spoke with people about the attacks and listened to their reactions. "He did this not because he felt it was his duty as a public service leader, but rather because he wanted to be with the people he represented" (McKenzie et al. 2001, 16).

By noon on September 11, securing New York City was not only a local effort, but also involved state and federal 
coordination. Some of the most significant support was provided by New York's governor's office. In Manhattan, when the attacks occurred, Governor George Pataki's first steps were similar to Richard Shierer's, and they included contacting the White House to secure the city's airspace while activating the state's Emergency Operations Center (Perez-Pena 2001). Next, Pataki put the National Guard on alert and declared a state disaster emergency. The latter declaration led to implementation of the state's disaster preparedness plan, which gave state agencies license to fully assist all relief and evacuation efforts in New York City. Pataki also called off the statewide elections in progress, including New York City's primary.

In the midst of making these decisions, Governor Pataki and senior emergency response officials joined Mayor Giuliani in the first of many press conferences. Though visibly shaken, the mayor conveyed his sentiments and all available information with a calm, composed approach. "I'd ask the people of New York City to do everything that they can to cooperate, not to be frightened, to go about their lives as normal. Everything is safe right now in the city. And the people who are doing the relief effort need all of the help they can get" (McKenzie et al. 2001, 4).

In this and subsequent press conferences, Giuliani acted as the primary spokesperson for the city. "While reassuring the public of the city's safety, he managed to communicate important logistical information such as the number of injured and missing people, details of the [World Trade Center] rescue effort. blood donation information, hospital traffic, transportation issues, and school closings" (Mashood et al. 2001, 5).

\section{Government Response after September 11, 2001}

In addition to hourly press conferences by Mayor Giuliani in the days and weeks following September 11, daily briefings were given by organizations such as the Federal Emergency Management Agency (FEMA). Appointed by FEMA director Joseph Allbaugh, Federal Coordinating Officer Ted Monette served as the agency's "personal representative on the ground during the duration" of the World Trade Center disaster (FEMA 2001a). As the hours passed, rescue and relief activities took priority over the relatively complete civilian evacuation. By this time, it was apparent that many emergency personnel who had entered the World Trade Center, as well as employees already in the towers, had not emerged when the South and North Towers fell. Monette's briefings emphasized FEMA's desire to locate survivors, as well as "to provide support and assistance to the city and the state for the response phase and long-term recovery" (FEMA 2001b).

By Wednesday morning, 2,250 National Guardsmen had relieved many of the NYPD and FDNY members who had been in lower Manhattan since the first attack. In addition, all of the NYPD's 41,000 officers had been called to duty by Tuesday afternoon, working in 12-hour shifts patrolling city streets and working in teams to search for survivors. In the burning rubble where the World Trade Center once stood-an area now referred to as "Ground Zero"FEMA and the FDNY, the latter of which had several hundred firefighters missing, supported the search for survivors, removal of the dead, and cleanup of an estimated 1.2 million tons of debris.

Starting on Friday, September 14, coordination for rescue and relief activities was administered from Pier 92, a huge shipping warehouse on the Hudson River, which the Office of Emergency Management had secured months prior in anticipation of a large-scale bioterrorism drill the agency had planned to hold on September 12. From this site, Richard Sheirer oversaw the distribution of resources to Ground Zero and supervised 300 to 500 emergency personnel from numerous city, state, and federal agencies (Crenson 2001). Here, many elected and appointed city officials congregated to review the previous day's events and plans for the next day's activities. Reflecting on the mayor's handling of these daily meetings, New York City comptroller Alan Hevesi stated that "regardless of any criticism you may have of the mayor, he was tremendous" (McKenzie et al. 2001, 13)

Perhaps the most visible department that Sheirer coordinated was FEMA. Meeting several times daily with the Office of Emergency Management, Ted Monette's FEMA operation took its cues from Richard Sheirer, and together they established a toll-free telephone line to identify and register all homes and businesses damaged by the attack (FEMA 2001c). Announcing the service through Web sites, newspapers, and press conferences, the hotline received more than 1,000 calls in the first week alone. For those homeowners and renters with legitimate grievances, grants were given for repairs and several months rent, to tide people over as their homes and offices were made habitable again. To ensure against multiple requests from the same complaint, Monette employed agents from FEMA's inspector general to cross-check claims against insurance claims and other agencies' support services.

Recognizing that some residents in affected areas might not be aware of the available FEMA support, Monette dispatched staffers who, in conjunction with nonprofit and religious aid workers, went door-to-door alerting people to the services and funding available. Speaking of the process, Monette stated, "the teams are a vital link between the community and relief agencies. This oneon-one contact helps us clear up situations that sometimes get in the way of providing the help people need" (Mashood et al., 18).

Complementing FEMA's door-to-door relief program was the "Ground Zero Task Force," a multilevel govern- 
ment initiative created by Congressman Jerrold Nadler. Representing the 8th District of New York, Nadler's constituents are some of the most diverse in the nation. In Washington, D.C., at the time of the attacks, Nadler's first meeting with multiple public officials occurred on the afternoon of Wednesday, September 12, where Giuliani convened all agency heads at the secretly located operations center, the Police Academy. "The congressman was amazed at the efficiency of this meeting. The mayor addressed one agency head at a time, told them what the city needed from them, and it was immediately done." (McKenzie et al., 14)

Recognizing the initial focus of government activity would be on rescue and recovery of those injured or killed during the attacks, Nadler created a task force to address a different population: the 25,000 residents of lower Manhattan. Nadler directed his relief efforts at individuals who had been displaced from their homes and people who were unable to care for themselves or access basic provisions, such as food, medicine, sanitation, and electricity, on their own. Comprising elected officials from the city, state, and federal levels, "the task force [maximized] operational efficiency because it created a direct communication link to disaster management officials" (McKenzie et al. 2001, 14). The task force supplied messengers to bring prescriptions to civilians who were unable to travel to pharmacies and negotiated with Verizon Wireless to provide cell phones to residents who had lost telephone lines.

While Mayor Giuliani, Richard Sheirer, and others worked to secure the city, New York Senators Hilary Clinton and Chuck Schumer worked to access federal funding for the city's relief and recovery efforts. Together, the two negotiated a federal commitment of $\$ 20$ billion for rescue, recovery, and rebuilding operations in New York City (Schumer 2002). This included $\$ 2.75$ billion in new funds for FEMA to help reimburse city and state agencies for overtime expenses and for replacement of destroyed or damaged equipment (Schumer 2002). The federal package also funded "clean-up costs, transportation infrastructure, utilities reconstruction, and economic stabilization for businesses and displaced workers" (Mashood et al. 2001, 17).

Complementing Senators Clinton and Schumer's fiscal objectives in Washington was an early analysis of the attack's fiscal impact by Comptroller Alan Hevesi. Hevesi's staff estimated that "The attack on the World Trade center will likely cost the City economy between $\$ 90$ billion and $\$ 105$ billion by the end of fiscal year 2002" (Press Office 2001). In addition to managing the financial affairs of the city, Hevesi and his campaign staff transformed his downtown office into a mini-disaster relief center. For several weeks, they collected supplies from corporate sponsors such as Timberland to donate to the relief effort. Reflecting on that first month after Septem- ber 11, Hevesi credits his leadership to his staff: "I am a delegator, and have nine deputy comptrollers who are experts and know more than me. I [was] simply the manager who provides resources and deals with other officials ... I am very proud of what we did as a team. We jumped in and we would not [have done] anything differently" (McKenzie et al. 2001, 13).

One of Comptroller Hevesi's rivals in the city's mayoral race, New York City council speaker Vallone, assisted the city's economic recovery effort by supporting legislation in the City Council to create a Lower Manhattan and Financial District Redevelopment Commission. In a press conference held soon after the attacks, Vallone stated, "September $11 \ldots$ created an economic crater that extends for miles around the World Trade Center" (McKenzie et al. 2001, 16). To help address the financial situation, this ninemember body would "facilitate and coordinate [the local government's part in] redevelopment and reconstruction of this area, and provide assistance to businesses located in the affected area.... Such efforts should be accomplished with the full cooperation of all City agencies, through public-private partnerships, and through coordination with federal and state authorities" (McKenzie et al. 2001, 16).

Introduction of legislation addressing the attacks occurred at both the state and federal levels. Congressman Nadler introduced a Public Safety Officer Benefit Program to compensate the families of officers who had been killed in the line of duty. Nadler drafted this legislation on the evening of September 12, introduced it in the House of Representatives at 10:40 the next morning, and had it passed in both houses of Congress 12 hours later. President George W. Bush signed it into law on the morning of September 14 (McKenzie et al. 2001, 14).

For all of the financial and legislative support provided at the state and federal levels, the primary focus after 9/11 remained in New York City. In the days and weeks following the attacks, Mayor Giuliani was New York's principal spokesperson. Beginning with a 7:00 a.m. strategy session with public officials from all levels of government (including Governor Pataki), the mayor's days included walking tours of Ground Zero to monitor the progress of the relief effort, as well as walking tours of hospitals and triage sites. Giuliani also held multiple press conferences each day to keep the public informed of relief and recovery efforts. "He also appeared almost daily on local and national news programs, each time touting the heroism of the rescuers and the bravery of New Yorkers" (Mashood et al. 2001, 5). Giuliani worked to inspire a sense of normalcy in his audience, be it public officials participating in the relief efforts or New York City residents watching him speak on television. He also encouraged New Yorkers to resist hatred against Arab nations and Arab Americans and to adopt a spirit of helping others. 
As the days between September 11 and the present turned to weeks, New York City public officials fulfilled their primary duties and the evolving responsibilities created by $9 / 11$. For months, Giuliani joined FDNY commissioner Von Essen as a full-time "comforter," attending countless funerals for fallen emergency personnel and other victims of the World Trade Center attacks. This particular role extended through the ranks, as described by Von Essen's September 15 comment that "every member of the fire department is either at a funeral, in a firehouse, or at ground zero" (Mashood et al. 2001, 9).

Just as job priorities shifted, so too did the expectations for public officials' definition of relief. One project that remained constant from the moment the Twin Towers collapsed through the spring of 2002 was the cleanup of Ground Zero. Though it shifted away from a rescue operation, more than 600 firefighters and hundreds of rotating volunteers worked 24 hours a day searching for survivors and remains in the rubble. Initially supervising this effort was Commissioner Von Essen, who "described the initial effort as similar to 'the way they built the pyramids,' bucket brigades of hundreds of people, moving smaller pieces of debris to clear a path so the larger pieces could be removed. In time, engineers and construction experts joined the effort, along with greater access to, and use of, heavy equipment" (Mashood et al. 2001, 9).

By January 1,2002, most of the rubble of the Twin Towers was gone. Sixteen weeks after the attacks, hotdog stands had replaced triage tents, and wooden beams supporting a viewing platform of Ground Zero obscured the remaining steel beams mangled by the collapse of the World Trade Center. And just as the landscape of lower Manhattan was changing daily, so too was there a changing of the guard. The mayoral primaries postponed on September 11 eventually took place, and in November 2001, financier Michael Bloomberg was elected mayor. With Giuliani's departure at the strike of midnight on New Year's Eve came the resignations of NYPD commissioner Bernard Kerik, FDNY commissioner Thomas Von Essen, and Office of Emergency Management director Richard Shierer, as well as the term endings for City Council President Peter Vallone and Comptroller Alan Hevesi.

Though many New York City government officials who became familiar to the public after September 11 are gone, their work has been neither forgotten nor abandoned by the change in administration. Despite Giuliani's effort to have his term extended, the transition took place, and a new administration continued the city's reconstruction. As superb as his leadership was in the days after $9 / 11$, the institutions of local government in New York City had proven durable and more than capable of peaceful and effective transition.

\section{The Catastrophe and Response Analyzed}

For the first several months after the attack on the World Trade Center, it was difficult to speak about the attack. Analysis seemed somehow trite and inappropriate. Still, as students of public management, we decided to ask our graduate students to research and analyze government's response to the attack. Some of the primary and secondary research reported in the previous section of this article came from that research effort. One of the coauthors of this piece was a teaching assistant during Columbia's fall 2001 public management course. We felt it essential to draw lessons from these events. While we resist the notion that a proper role of research is catharsis, we admit that we began this research as a self-conscious strategy to help our community deal with this terrible tragedy.

What is most striking is the skill and intensity of government's response to the emergency: The quick thinking of the PATH officials sending a train of passengers back to New Jersey and an empty train to Manhattan to facilitate evacuation. The decisions in the local schools near the World Trade Center to evacuate and for the rest of the city's schools to remain in session, taking particular care in ensuring that all children were met by adults at the end of the day. Decisions to close the bridges, ports, and airports, and of course the mayor's inspiring personal leadership in the first hours and then first weeks after the attack.

The first finding is that planning for emergencies was clearly present in New York City and helped to mitigate the impact of the attack. The modern city is a complex, interdependent system. These systems have redundancies, but also great vulnerabilities. Mayor Giuliani recognized the fragility of the city's systems and developed the organizational capacity for emergency response. When some of us outside of government criticized his penchant for security, he proved his critics wrong. While his selection of a location for an emergency coordination facility turned out to be a mistake, the planning, training, and communication infrastructure built for catastrophe proved worthwhile. More important, the capacity was matched with an unparalleled effort at intergovernmental coordination.

The daily, high-level, early-morning coordination meeting was an innovative way to ensure that communication and feedback was routinized. In this era of email and cell phones, face-to-face communication proved essential. This points to an area of research that should be undertaken: What is the effect of new electronic communications techniques on organizational behavior? Why does face-to-face communication remain an essential element of a well-managed organization? In what respect does sound written communication and even televised communication need to be amplified by in-person, three-dimensional, tactile communications? 
There has been expert discussion of the field-communication failures that resulted in delayed evacuation and the death of hundreds of firefighters. Here, the lesson is straightforward - the need for emergency workers to possess the most modern communications equipment. However, the broader lesson is that despite the failures of many primary methods of communication, back-up systems worked, emergency response personnel appeared at the scene based on mass media reports, and prearranged emergency response procedures dominated. The overall image from the scene was a calm (perhaps stunned) and orderly evacuation. There was little panic and no disorder.

The New York Fire Department has gone through an intense period of self-evaluation to reexamine the standard operating procedures that resulted in the large number of fatalities suffered by the department. According to one early assessment, "Jolted by the mass deaths of rescuers in New York, firefighters won't be so quick to rush into burning high-rises and will broadly rethink how to protect themselves while trying to save others.... They will review how they confront big fires in high-rises, defend rescuers from secondary terrorist attacks, train for collapse-prone buildings, keep command centers safe, and prepare and equip themselves for chemical and biological weapons" (Donn 2001). The New York Fire Department's own internal assessment cited communication breakdowns as a major cause of the failure to evacuate the towers after the order to do so was given. According to one report, "Much of the difficulty was a result of hundreds of firefighters who had responded though not on duty at the time. They came by taxi, subway and bus, by foot, or by crowding on to fire trucks on their way to the site. When the order to evacuate came, that meant that many firefighters did not have radios and the department did not know how many were in the twin towers or where they were.... The Fire Department ... does not know why more of its personnel did not evacuate the towers... It was possible that firefighters had not heard the order, were unable to get out quickly enough, were unable to receive radio transmissions because of an equipment malfunction, or felt they could save a life by staying" (Lipton and Glanz 2001, B4).

The lesson here is that in addition to improved communications equipment, firefighters must reexamine their own standard operating procedures. The direct-response culture of the department saves lives in most situations, but it may be inappropriate in the case of catastrophes such as $9 / 11$.

At the time of the World Trade Center collapse, it was obvious to many that the City of New York was under attack, and the many media-induced images of collective response and pulling together clicked into effect as people moved to help each other and escape the scene. The image of the World Trade Center's collapse was, for many people, like a scene from a science fiction movie. While we could imagine such an event, the fact of its occurrence in real life registered, but in some way remained unreal. The effect of these images and these events on mass behavior was visible in New York City, and in coming years it should be the subject of detailed analysis.

The decentralization of municipal administration and the size of New York City worked in its favor during and after the attack. Emergency crews arrived on the scene without direct orders to do so. In some cases, they acted according to prearranged emergency plans, and in other cases they came out of a sense of duty and responsibility. Decisions by the Board of Education, school principals, teachers, and New York City commissioners were made without waiting for clearance from above. Because the image of a worst-case emergency scenario existed in the minds of many key decision makers, they responded to these images with actions that were decisive and clear.

A depth of leadership throughout the city was demonstrated on that day and in the following weeks. In our view, our information-based, complex society has provided a leadership culture that permits and possibly encourages innovation. Clearly, this is a researchable question. The Giuliani administration was highly centralized on normal days, but during an emergency, leadership action was inspired, orderly, and creative. Why?

This leads to another finding for planners and policy makers and the need to learn more about the impact of wartime mobilization on people and organizations. The World Trade Center site was cleared of debris about a year ahead of schedule. The number-one subway line tunnel under the World Trade Center was scheduled to reopen to South Ferry nine months ahead of schedule. Partisan politics disappeared from view for at least 60 days. Democratic senators and representatives worked as a team with a Republican governor and mayor. The feuding governor and mayor ended their conflict, with the mayor playing the role of lead responding official and the governor the role of ally and supporter bringing state resources to bear on the crisis. Why?

We have seen this phenomenon during other emergencies. Workers during the home-front mobilization in World War II worked hard and produced at an extraordinary rate. According to one account, at the start of World War II,

... Our army had more horses than tanks and Nazi U-boats were sinking American merchant ships with shocking ease. It took a tremendous exercise of American will and power to turn the tide, a national mobilization such as this country had never seen before, and may never see again. And fueling it was raw revenge, retribution for the humiliating defeat at Pearl Harbor. Pearl might be the greatest American victory of the war. It awoke a sleeping giant. But it took almost no time to re-tool the economy 
for wartime production. The world's greatest automobile society stopped making cars during the war and geared its auto plants to the production of every imaginable instrument of mobile warfare. At Henry Ford's gigantic new plant at Willow Run, outside Detroit, an assembly line a mile long poured out B24 bombers at a rate of a plane every 63 minutes... America was a third rate military power in 1940. By 1945 it was producing more weapons and firepower than the rest of the world put together. (Anneneberg/ CPB 2002, 1234)

On a smaller scale, we saw a similar mobilization after 9/11. The threat being more subtle than World War II, the mobilization was as well. But clearly, Ground Zero in New York City provided a less than subtle message. The endless loop of video tape seen by us all of the World Trade Center's collapse, and the faces of the members of families that had lost loved ones, provided a high level of motivation for workers clearing debris or constructing new tunnels. How does this process work in this type of war, and is it different than World War II? Does instant and ubiquitous communication intensify or reduce our reaction to these events?

We had assumed by the spring of 2002 that the financial and organizational effect of the World Trade Center attack would be more obvious than it is. The impact on the city's economy has been felt primarily through a decline in tourism. The recession that began before 9/11 was intensified by the attack, and New York City's government budget faced a $\$ 4$ billion $-\$ 5$ billion deficit in the following fiscal year. The Port Authority of New York and New Jersey lost leadership, staff, and its headquarters, and in many respects it may never recover from the attack. On a daily basis, in mid-2002, the city struggled to provide the resources needed to fund public education, maintain the nation's largest local police force, clean the streets of garbage, and care for its aged, sick, and poor population. The resources that were so plentiful in the late 1990s are suddenly scarce again in the early twenty-first century. Despite considerable displays of bravado, those of us who live here, young and old, feel a sense of vulnerability and sadness that fades, but never disappears.

The remedial economic impact of reconstruction is also difficult to project. The planning process for reconstruction has been slow and difficult as planners address a wide range of agendas. Some victims' families would like to see the entire site turned into a memorial. Residents in nearby Battery Park City would like to see reconstruction provide a more human-scale set of streets and buildings. There are, of course, financial interests that would like to make money from redevelopment. Some in the tourist industry see a major $9 / 11$ memorial as a lure to worldwide tourism. The economic impact of this reconstruction will be felt throughout the region, but is impossible to measure at this point. Estimates of the Regional Plan Association and others are so contingent that they are best thought of as educated guesses. The early analysis of Comptroller Hevesi of a total financial cost of about $\$ 100$ billion over two years has yet to be refuted.

\section{Lessons Learned}

What did we learn, then? We learned some prosaic operational lessons that we should take care to record:

- Emergency response planning is essential.

- Emergency response institutions, procedures, and resources must be retained, even when threats seem distant.

- Communications systems must be made more redundant. Cellular and wired emergency communications systems must have at least two levels of backup to reduce the odds of failure during emergencies.

- Emergency response procedures must assume communication breakdowns and allow for decentralized decision making.

- There is no substitute for inspiring leadership during a crisis.

However, the more profound lesson we learned is that public service and the ethos of public service are as important as ever. We saw government workers die by the hundreds in performance of their duty. We saw elected officials cast aside partisanship and work together as a team to manage the emergency response, reassure the public, and organize for recovery. We saw strength, patriotism, creativity, and incredible dedication to task, from the mayor to the volunteer passing buckets of rubble down a human chain of rescue workers. The key lesson of 9/11 for public administration is the restatement and reassertion of our central guiding principle, the one that always appears on the inside back cover of this journal: Serve the Public Interest. Serve the public, beyond serving oneself. When the catastrophe came, our government, nonprofits, and citizenry, for the most part, responded and lived up to this principle. Public service is hardwired into our cultureinto our government, our institutions, and our people. Despite the materialism, cynicism, and doubts reported so frequently by the media, when we need to, we remain capable of demonstrating creative, capable, and compassionate public service. Those of us living in New York City in the autumn of 2001 experienced that first-hand. It is something we will never forget. 


\section{References}

Annenberg/CPB. 2000. A Biography of America, World War II, 1941-1945. The Home Front. Available at http://w'w wearner: org/resources/resource.html? uid $=123 \& s j=$. Accessed June $18,2002$.

Archibold, Randal C. 2001. Battery Park Set to Reopen to Residents of North End. New York Times. Dow Jones Interactive, September 20. Available at http://www:columbia.edu/cullibraries/indexes/dow-jones-inter.html. Accessed March 15 , 2002.

ArcNews Online. 2002. Managing Chaos Relies on Fast, Accurate Information. April 1. Available at http:/ww'wesricom new's/archives/winter0102articles/nyc-creating.html. Accessed November-December, 2001.

Bowles, Pete. 2002. Terrorist Attacks/Mayor's Emergency Center Falls. New'sday, September 12, W41. Dow Jones Interactive. Available at http://ww'u'columbia.edu/cullibraries/indexes/dow-jones-inter.html. Accessed March 15, 2002.

Campo-Flores, Arian. 2001. Saving New York. Newsweek.com, September 15. Available at http:/w'w'msnbc.com/new's/NWfront Front asp. Accessed June 18, 2002.

CBS News. 2002. 48 Hours at Ground Zero. CBS News Online. September 28. Available at http://www.cbsnews.com/stories 2001/09/28/48hours/main312902.html. Accessed April 1, 2002.

Crenson, Sharon L. 2001. City Commanders Make Do in Wake of Trade Center Attacks. Associated Press State and Local Wire. Dow Jones Interactive, September 20. Available at http://ww'columbia.edu/cullibraries/indexes/dow-jonesinter. html. Accessed April 2002.

Donn, Jeff. 2001. Firefighters Thinking More of Own Safety after Trade Center Disaster. Associated Press Newswire, October 15. Available at http://wire.ap.org/APnew's/?SITE= NYMEL\&FRONTID =HOME. Accessed June 18, 2002.

Federal Emergency Management Agency (FEMA). 2001 a. FEMA Damage Inspectors Visit Assistance Applicants. Information on Federally Declared Disasters, September 25. Available at http://wh' fema.gov/diz01/d139ln12.html. Accessed June 18, 2002.

2001b. One Week after Terrorist Attacks, Site Clearance and Facilities Restoration Continues. Federal Emergency Management Agency New's Room, September 18. Available at http://n'w fema.gov/nwzOl/nwzol_114.html. Accessed November-December 2001.

_ 2001c. President Orders Disaster Aid for New York Terrorist Attack. Information on Federally Declared Disasters, September 11. Available at http://www.fema.gov/diz01/ d1391 n01.html. Accessed June 18, 2002.

Griscom, Amanda. 2001. Man Behind the Mayor. New York Magazine, October 15. Available at http://www.nymag.com/ page.cfm?page_id=5270. Accessed on June 18, 2002.

Lipton, Eric, and James Glanz. 2002. Ground Zero Firefighting: 9/11 Inspires Call to Review Response Plan for Crises. New York Times, January 23, B4.
Marzulli, John. 1999. Secret Plan to Safeguard City. New' York Daily News, December 30, 6 .

- 2001. Giuliani and Group of Top Cops Barely Dodged Death as Towers Fell. Daily News, September 27, 22.

Mashood, Issaka, Aimee Herbert, Noriko Kaiser, Katherine Lapham, Susan Neva, Iara Peng, Zolaika Salihi, Rebecca Scheer, Nicole Sebastian, Jennifer Sklar, Daphne Stavropolous, Katherine Stoehr, Yuki Taketani, Trin Thamkittikasem, Allison Tractman, Nicole Valenti, Yasuyuki Watanabe, and Chunyu Yu. 2001. Evaluation of Public Sector Response to the 2001 WTC Attack. Unpublished seminar paper. Columbia University, School of International and Public Affairs, Graduate Program in Public Policy and Administration.

McKenzie, Peter, Marisela Perez, Laura Schmisskiss, Parita Shah, and Raissa Smorol. 2001. A Paradigm of Leadership: Lessons Learned from Public Service Leaders in the Aftermath of September 11, 2001. Unpublished seminar paper. Columbia University, School of International and Public Affairs, Graduate Program in Public Policy and Administration.

McPhee, Michele, and Patrice O'Shaughnessy. 2001. The Great Rescue of September 11. New York Daily New's, November $11,4$.

NYC.gov, Department of Corrections. 2002. Former Commissioner Kerik Becomes New Police Commissioner. DOC Web Archives, Department of Corrections, New York City, April 1. Available at http://www.nyc.gov/html/doc/html/ pscshield.html. Accessed June 18, 2002.

Perez-Pena, Richard. 2001. Giuliani Closes Lower NYC. Pittsburgh Post-Gazette, September 12, A19.

Press Office of New York City Comptroller William C. Thompson, Jr. 2001. Trade Center Attack Could Cost City Economy More than $\$ 100$ Billion Over 2 Years: City Will Need Additional Federal Aid to Recover. Available at http://www. Comptroller:nyc.gov/press/2001_releases/. Accessed June 18, 2002.

Rashbaum, William K. 2001. Police Officers Swiftly Show Inventiveness during Crisis. New York Times, September 17, A7.

Sandberg, Jared. 2001. Aide to Mayor Quietly Handles New York Rescue Effort. Wall Street Journal, September 21, A10.

Schumer, Charles E. 2002. Schumer: White House Makes Good on $\$ 20$ Billion Pledge to Aid NY Recovery. Press Room Web site of Senator Charles E. Schumer, March 7. Available at http://schumer.senate.gov/SchumerWebsite/pressroom/ press_releases/PR00877.html. Accessed June 18, 2002.

Schwaneberg, Robert. 2001 . P.A. Staffers Ignored Danger. StarLedger, September 14, 13.

Seifman, David. 2001. Rudy's Courage a Beacon for Us All. New'York Post, September 17, 20.

Wall Street Journal. 2001. A Day of Terror: Attacks Bring Closings across the Nation and Overseas. September 12, A4. 